\title{
AKTIVITAS ANTIBAKTERI SEDIAAN SABUN CAIR BERBAHAN AKTIF EKSTRAK ETANOL DAUN KARAMUNTING (Melastoma malabathricum)
}

\author{
Femy Linggi Allo, Lizma Febrina, Laode Rijai \\ Laboratorium Penelitian dan Pengembangan FARMAKA TROPIS, Fakultas Farmasi, \\ Universitas Mulawarman, Samarinda, Kalimantan Timur \\ Email:femylinggi@gmail.com
}

\begin{abstract}
ABSTRAK
Karamunting merupakan tumbuhan yang dapat tumbuh liar dan berlimpah di seluruh daerah tropis. Daun karamunting telah diketahui memiliki khasiat sebagai antibakteri. Salah satu cara pemanfaatan yang dapat dilakukan adalah dengan mengaplikasikan ekstrak etanol daun karamunting dalam produk sabun cair. Penelitian ini bertujuan untuk mengetahui aktivitas antibakteri ekstrak etanol daun karamunting dan sediaan sabun dengan bahan aktif ekstrak etanol daun karamunting khususnya terhadap bakteri Escherichia coli dan Staphylococcus aureus. Pengujian aktivitas antibakteri dilakukan dengan metode difusi agar. Hasil penelitian menunjukkan bahwa aktivitas antibakteri ekstrak etanol daun karamunting dengan konsentrasi 1\%, 2\%, 3\%, 4\% dan 5\% terhadap bakteri Escherichia coli dan Staphylococcus aureus memiliki respon hambatan pertumbuhan termasuk dalam kategori lemah sampai sedang dengan zona hambat dan zona bunuh antara 1-10 mm. Sedangkan aktivitas antibakteri sediaan sabun cair dengan bahan aktif ekstrak etanol daun karamunting memiliki respon hambat yang lebih besar dibandingkan sediaan sabun cair tanpa bahan aktif ekstrak etanol daun karamunting.
\end{abstract}

Kata kunci: Melastoma malabathricum, Escherichia coli, Staphylococcus aureus, Antibakteri, Sabun cair

\begin{abstract}
Melastoma malabathricum is a plant that grows wild and abundant in all tropical areas. Melastoma malabathricum leaves has been known to have antibacterial properties. One way of to do is to apply the melastoma malabathricum leaves ethanol extract in liquid soap products. This study aims to determine the antibacterial activity of the melastoma malabathricum leaves ethanol extract and liquid soap with active ingredient melastoma malabathricum leaves ethanol extract, especially against Escherichia coli and Staphylococcus aureus. Antibacterial activity test performed by the agar diffusion method. The results showed that the antibacterial activity of melastoma malabathricum leaves ethanol extract with a concentration of 1\%, 2\%, 3\%, 4\% and 5\% of the bacteria Escherichia coli and Staphylococcus aureus has the growth inhibition responses are included in the category of weak to moderate with inhibition zone and kill zones between 1-10 mm. While the antibacterial activity of preparation liquid soap with active ingredient melastoma malabathricum leaves ethanol extract have a greater inhibitory response than preparation liquid soap without active ingredients melastoma malabathricum leaves ethanol extract.
\end{abstract}


Keywords: Melastoma malabathricum, Escherichia coli, Staphylococcus aureus, Antibacterial, Liquid soap

\section{PENDAHULUAN}

Karamunting (Melastoma malabathricum) merupakan tumbuhan yang dapat tumbuh liar dan berlimpah di seluruh daerah tropis, termasuk Indonesia. Tumbuhan ini banyak digunakan oleh masyarakat sebagai obat untuk mengobati berbagai jenis penyakit, diantaranya pengobatan disentri, diare, luka dan infeksi karena bakteri. Metabolit sekunder yang terkandung dalam ekstrak etanol daun karamunting antara lain flavonoid, saponin, tanin, glikosida, steroid dan triterpenoid ${ }^{[1]}$.

Ilmu pengetahuan dan teknologi yang sangat berkembang pesat membuat daun karamunting dapat digunakan sebagai bahan baku dalam industri farmasi. Hal ini disebabkan karena tanaman obat sering dianggap kurang beracun dan memiliki efek samping yang lebih rendah dibandingkan dengan bahan kimia sintesis. Salah satu cara pemanfaatan yang dapat dilakukan adalah dengan mengaplikasikannya dalam produk sabun cair.

Sabun merupakan bahan pembersih yang telah lama digunakan orang karena dapat menghilangkan kotoran-kotoran seperti debu, bakteri dan sisa metabolisme atau keringat sehingga dapat mencegah terjadi infeksi pada kulit ${ }^{[2]}$. Sabun terbentuk karena terjadinya proses saponifikasi yaitu reaksi hidrolisa asam lemak oleh basa lemah. Salah satu sumber asam lemak adalah minyak kelapa sawit yang dipasaran banyak beredar dalam bentuk minyak goreng.

Hal inilah yang menjadi dasar pemikiran dilakukan penelitian aktivitas antibakteri sediaan sabun cair dengan bahan aktif ekstrak etanol daun karamunting.

\section{METODE PENELITIAN}

\section{Bahan}

Bahan yang digunakan pada penelitian ini adalah simplisia daun karamunting, pelarut etanol 96\% untuk ekstraksi, paper disc, medium NA (Nutrient Agar), $\mathrm{NaCl}$ 0,9\% sebagai pensuspensi bakteri, minyak kelapa sawit sebagai asam lemak pembentuk sabun, kalium hidroksida $(\mathrm{KOH})$ sebagai alkali pembentuk sabun, kalium karbonat $\left(\mathrm{K}_{2} \mathrm{CO}_{3}\right)$ dan air suling sebagai pelarut. Bakteri uji yang digunakan adalah Escherichia coli dan Staphylococcus aureus.

\section{Alat}

Alat-alat yang digunakan dalam penelitian ini antara lain wadah maserasi, rotary evaporator, timbangan analitik, cawan porselin, labu ukur, tabung reaksi, mikropipet, autoklaf, inkubator, cawan petri, labu erlenmeyer, spoit injeksi, botol pengencer, LAF (Laminar Air Flow), mikrometer sekrup, mixer, hot plate, panci stinless steel, termometer, spatula, batang pengaduk, ose bulat, gelas kimia, batang pengaduk dan magnetic stirrer.

\section{Prosedur penelitian}

\section{Ekstraksi}

Simplisia daun karamunting dimasukkan ke dalam wadah maserasi dan dimaserasi menggunakan pelarut etanol. Proses maserasi berlangsung selama kurang lebih 3 hari. Maserat (hasil maserasi) disaring menggunakan kertas saring dan ditampung ke dalam wadah. Kemudian maserat dipekatkan menggunakan rotary evaporator dan dilanjutkan dengan penguapan hingga diperoleh ekstrak etanol kental. 


\section{Pengujian Aktivitas Antibakteri Ekstrak}

Aktivitas antibakteri pada pengujian ini dilakukan dengan metode difusi agar. $10 \mathrm{~mL}$ Medium NA dicampurkan dengan 0,02 mL suspensi bakteri 1:40 di dalam botol pengencer, dikocok hingga benar-benar homogen, kemudian dituang dituangkan ke dalam cawan petri dan dibiarkan hingga medium setengah padat. Setelah itu paper disc steril yang telah direndam dalam ekstrak etanol dengan 5 seri konsentrasi, diletakkan diatas permukaan medium. Kemudian diinkubasi pada suhu $37^{\circ} \mathrm{C}$ selama 24 jam. Kontrol negatif digunakan paper disc yang telah direndam dalam air suling sebagai pelarut ekstrak daun karamunting.

\section{Pembuatan Sediaan Sabun Cair}

Proses pembuatan sabun cair dilakukan dalam 2 tahap, yaitu pembuatan pasta sabun dan pembuatan sabun cair. Tahap pertama yaitu pembuatan pasta sabun cair dimana minyak kelapa sawit yang digunakan dimasukkan dalam panci stinless steel sambil dipanaskan pada suhu $80{ }^{\circ} \mathrm{C}$. Setelah minyak mencapai suhu $80{ }^{\circ} \mathrm{C}$, dilakukan pencampuran larutan alkali yaitu $\mathrm{KOH}$ dan $\mathrm{K}_{2} \mathrm{CO}_{3}$ dengan air suling pada wadah yang lain. Larutan alkali kemudian dituangkan ke dalam campuran minyak secara perlahan lahan sambil diaduk hingga mencapai tahap trace dan suhu diatur hingga mencapai $70{ }^{\circ} \mathrm{C}$. Tahap trace adalah tahap ketika sabun menyusut, lalu mengental dan membentuk padatan. Dicek pasta sabun dan lakukan pengadukan dengan interval waktu 20 menit selama 3 jam hingga pasta sabun mencapai tahap vaseline (padat dan lunak).

Tahap kedua yaitu pembuatan sabun cair dengan cara mendilusikan pasta sabun cair yang telah terbentuk dalam air agar menjadi sabun cair. Sediaan sabun cair dibuat dengan cara melarutkan pasta sabun dalam air mendidih dengan perbandingan 1:5. Penambahan pasta sabun kedalam air dilakukan sedikit demi sedikit untuk menjaga agar sabun tetap homogen. Kemudian diaduk perlahan ditutup wadah dan matikan pemanas. Dibiarkan sabun larut dengan air dan dibiarkan sabun hingga dingin. Setelah sabun dingin dimasukkan ekstrak daun karamunting agar bahan aktif tidak rusak dan diaduk menggunakan magnetic stirrer hingga ekstrak tercampur sempurna.

\section{Pengujian Antibakteri Sabun Cair}

$10 \mathrm{~mL}$ Medium NA dicampurkan dengan 0,02 mL suspensi bakteri 1:40 di dalam botol pengencer, dikocok hingga benar-benar homogen, kemudian dituang dituangkan ke dalam cawan petri dan dibiarkan hingga medium setengah padat. Setelah itu paper disc steril yang telah direndam dalam sediaan sabun cair, diletakkan diatas permukaan medium. Kemudian diinkubasi pada suhu $37{ }^{\circ} \mathrm{C}$ selama 24 jam.

\section{HASIL DAN PEMBAHASAN}

Pengujian aktivitas antibakteri ekstrak etanol daun karamunting terhadap bakteri Escherichia coli dan Staphylococcus aureus dilakukan dengan menggunakan 5 konsentrasi yaitu $1 \%, 2 \%, 3 \%, 4 \%$ dan 5\%. Hasil uji aktivitas antibakteri ekstrak etanol daun karamunting menunjukkan ekstrak etanol dengan konsentrasi 1\%, 2\%, 3\%, 4\% dan 5\% membentuk zona hambat di sekitar paper disc (Gambar 1.), yang menandakan adanya aktivitas penghambatan terhadap pertumbuhan bakteri uji, sedangkan pengujian air suling sebagai kontrol negatif menunjukkan hasil berupa tidak terbentuknya zona hambat di sekitar paper disc. Tidak terbentuknya zona hambat oleh air suling membuktikan bahwa air suling yang digunakan sebagai pelarut untuk membuat variasi konsentrasi ekstrak tidak berpengaruh terhadap penghambatan pertumbuhan bakteri, sehingga akitivitas antibakteri yang dihasilkan oleh larutan uji ekstrak hanya berasal dari kandungan senyawa di dalam ekstrak tersebut, bukan dari pelarut yang digunakan. Pada Gambar 1. terlihat pada konsentrasi $1 \%$ sampai 5\% terlihat adanya zona hambat, dimana semakin tinggi 
konsentrasi maka zona hambat yang terbentuk akan semakin besar. Hal ini diduga karena jumlah senyawa antibakteri akan semakin besar dengan adanya penambahan konsentrasi sehingga mempermudah penetrasi senyawa tersebut ke dalam sel bakteri.

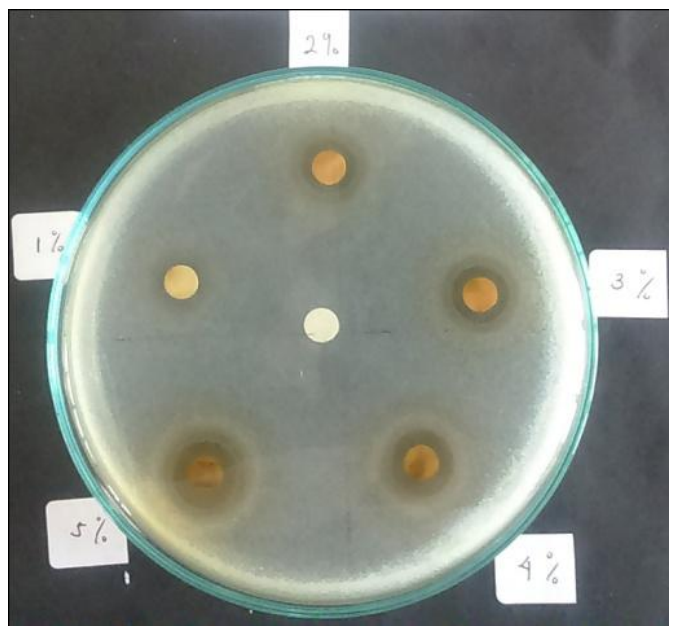

(a)

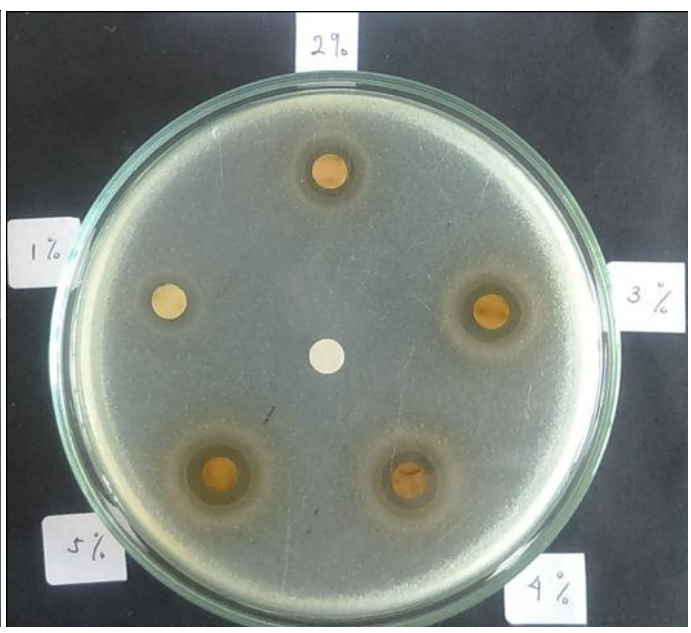

(b)

Gambar 1. Aktivitas antibakteri ekstrak etanol daun karamunting terhadap bakteri (a) Escherichia coli dan (b) Staphylococcus aureus

Data aktivitas antibakteri ekstrak etanol daun karamunting terhadap bakteri Escherichia coli dan Staphylococcus aureus dapat dilihat pada Tabel 1.

Tabel 1.Data aktivitas antibakteri ekstrak etanol daun karamunting

\begin{tabular}{cccc}
\hline \multirow{2}{*}{ Sampel Uji } & \multirow{2}{*}{ Konsentrasi } & \multicolumn{2}{c}{ Rerata Diameter Zona Hambat (mm) } \\
\cline { 3 - 4 } & & Escherichia coli & Staphylococcus aureus \\
\hline \multirow{2}{*}{ Ekstrak Etanol } & $1 \%$ & 4,546 & 4,689 \\
Daun & $3 \%$ & 6,481 & 6,041 \\
Karamunting & $4 \%$ & 6,833 & 6,867 \\
& $5 \%$ & 8,282 & 7,219 \\
\hline Air Suling & - & 10,295 & 9,256 \\
\hline
\end{tabular}

Tabel 1. menunjukkan bahwa aktivitas antibakteri ekstrak etanol daun karamunting dalam menghambat pertumbuhan bakteri Escherichia coli dan Stapyhlococcus aureus pada konsentrasi $1 \%$ termasuk dalam kategori lemah dengan nilai zona hambat kurang dari 5 mm, sedangkan pada konsentrasi $2 \%, 3 \%, 4 \%$ dan 5\% termasuk dalam kategori sedang dengan nilai zona hambat antara 5-10 $\mathrm{mm}$. 


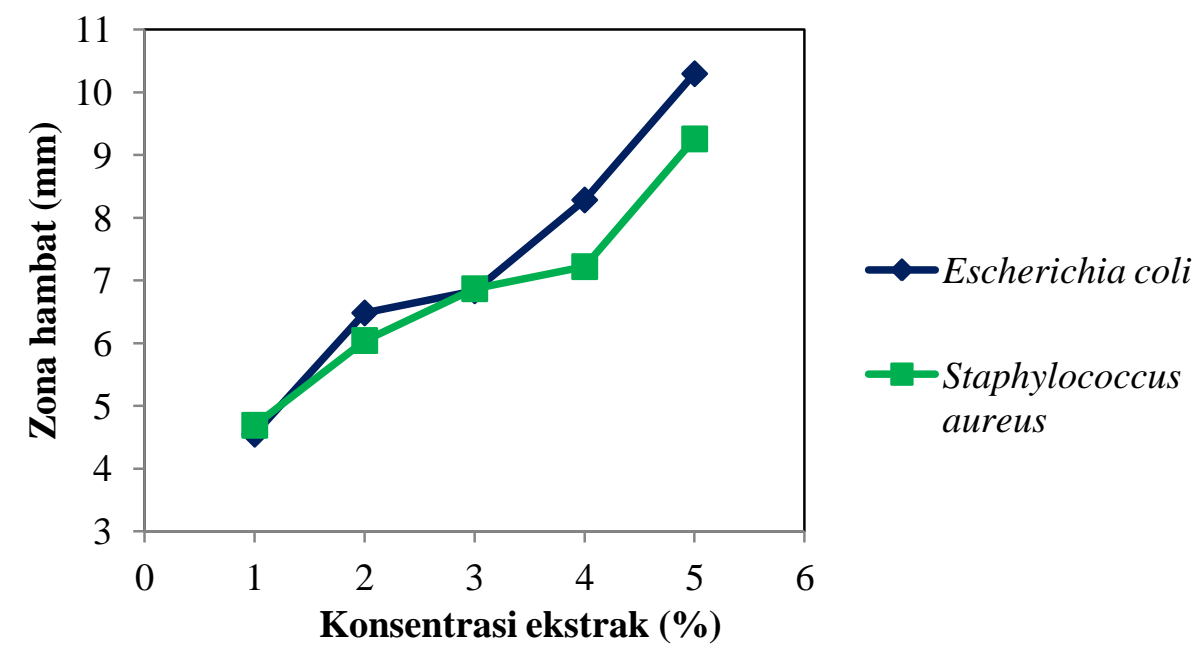

Gambar 2. Grafik aktifitas antibakteri ekstrak etanol daun karamunting dalam menghambat pertumbuhan bakteri uji Escherichia coli dan Stapyhlococcus aureus

David dan Stout (1971) dalam Rita ${ }^{[3]}$ menjelaskan bahwa apabila zona hambat yang terbentuk pada uji difusi agar berukuran kurang dari $5 \mathrm{~mm}$ dikategorikan lemah, 5-10 mm dikategorikan sedang, 10-20 dikategorikan kuat dan $20 \mathrm{~mm}$ atau lebih dikategorikan sangat kuat.

Sabun cair dibuat menggunakan bahan dasar minyak goreng yang terbuat dari minyak kelapa sawit. Minyak kelapa sawit merupakan minyak nabati yang mengandung asam lemak, seperti asam palmitat $(44 \%)$, asam stearat $(4,6 \%)$, asam miristat $(1 \%)$ dan sisanya adalah asam linoleat $(38,7 \%)^{[4]}$. Selain minyak, bahan yang digunakan untuk membuat sabun cair adalah $\mathrm{KOH}$ dan $\mathrm{K}_{2} \mathrm{CO}_{3}$.

Tabel 2. Komposisi pasta sabun cair

\begin{tabular}{cc}
\hline Bahan & Jumlah (gram) \\
\hline Minyak kelapa sawit & 121 \\
$\mathrm{KOH}$ & 28 \\
$\mathrm{~K}_{2} \mathrm{CO}_{3}$ & 5 \\
Air suling & 300 \\
\hline
\end{tabular}

$\mathrm{KOH}$ berfungsi sebagai basa alkali yang digunakan dalam pembuatan sabun. Sedangkan $\mathrm{K}_{2} \mathrm{CO}_{3}$ merupakan garam kalium yang dapat membuat konsistensi dari sabun menjadi cair dan lunak. Terdapat beberapa faktor penting yang harus diperhatikan ketika pembuatan sabun mandi berlangsung diantaranya adalah suhu pemanasan dan pengadukan. Pemanasan dilakukan untuk merenggangkan ikatan antara gugus karboksilat yang terdapat dalam minyak terhadap alkali, sehingga reaksi saponifikasi dapat terjadi. Pengadukan selama proses pembuatan sabun diperlukan untuk mendapatkan campuran larutan yang homogen. Apabila tidak dilakukan pengadukan maka bahan tidak akan tercampur dengan rata dan menggumpal yang akan mempengaruhi tampilan sabun cair. Penampakan sediaan sabun cair tanpa ekstrak etanol daun karamunting dan sediaan sabun cair dengan ekstrak etanol daun karamunting yang telah dibuat dapat dilihat pada Gambar 3. 


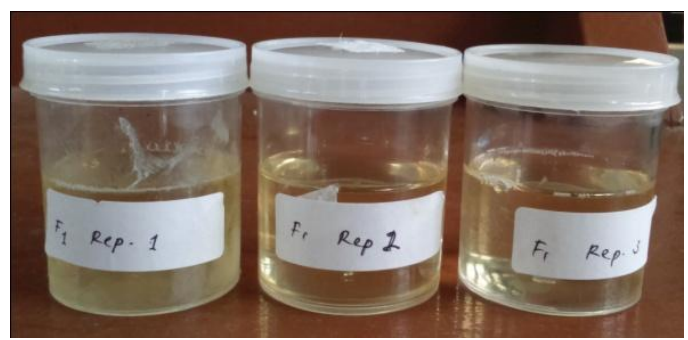

(a)

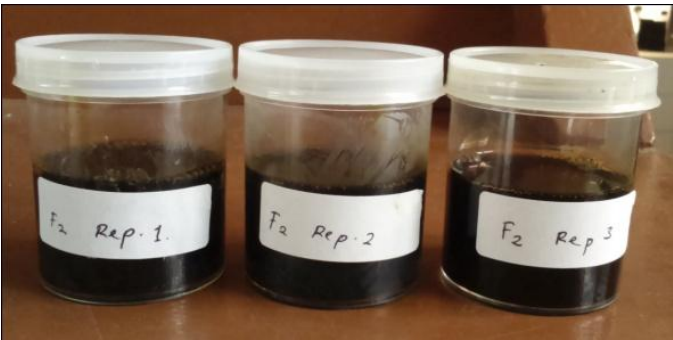

(b)

Gambar 3. Sedian sabun cair (a) tanpa ekstrak etanol daun karamunting dan (b) dengan ekstrak etanol daun karamunting

Uji antibakteri sediaan sabun cair dilakukan dengan cara yang sama seperti pada uji antibakteri ekstrak etanol daun karamunting. Konsentrasi ekstrak etanol daun karamunting yang dimasukkan dalam sediaan sabun cair adalah $2 \%$. Hal ini didasari pada bahan aktif yang sering digunakan pada sediaan sabun cair yaitu golongan fenol, seperti triklosan. Konsentrasi triklosan sebagai antiseptik adalah $0,05 \%$ sampai dengan $2 \%{ }^{[5]}$.

Data aktivitas antibakteri sediaan sabun cair terhadap bakteri uji dapat terlihat pada Gambar 4. dan Tabel 3.

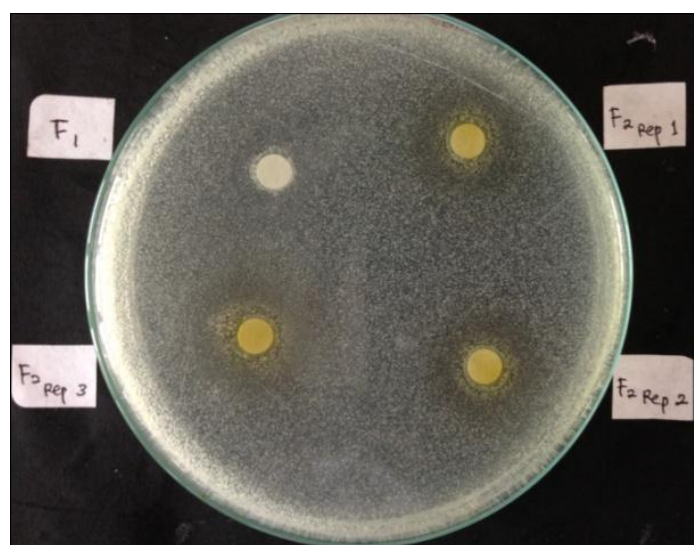

(a)

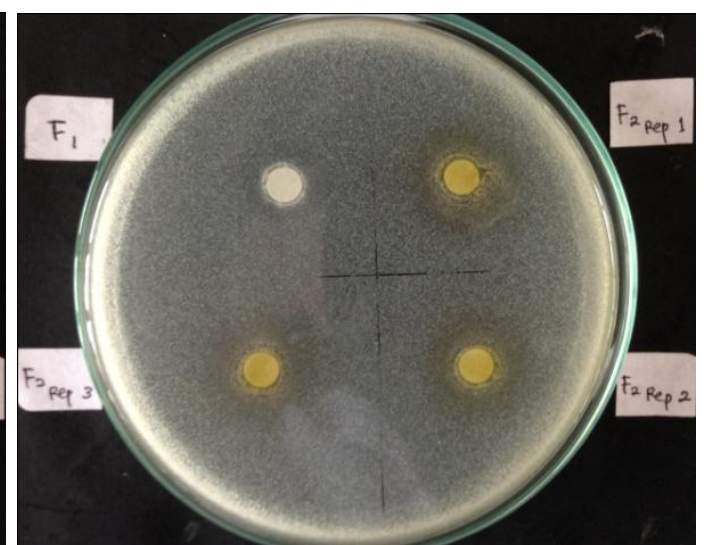

(b)

Gambar 4. Aktivitas antibakteri sediaan sabun cair terhadap bakteri (a) Escherichia coli dan (b) Staphylococcus aureus. $\mathrm{F}_{1}=$ Sediaan sabun cair tanpa ekstrak etanol daun karamunting dan $\mathrm{F}_{2}=$ Sediaan sabun cair dengan ekstrak etanol daun karamunting

Tabel 3. Data aktivitas antibakteri sediaan sabun cair

\begin{tabular}{ccc}
\hline \multirow{2}{*}{ Sampel Uji } & \multicolumn{2}{c}{ Rerata Diameter Zona hambat (mm) } \\
\cline { 2 - 3 } & Escherichia coli & Staphylococcus aureus \\
\hline $\mathrm{F}_{1}$ & 6,445 & 7,378 \\
$\mathrm{~F}_{2}$ & 12,353 & 11,821 \\
\hline
\end{tabular}


Dari gambar dan tabel diatas hasil uji antibakteri sediaan sabun cair tanpa bahan aktif ekstra etanol daun karamunting $\left(\mathrm{F}_{1}\right)$ dan sediaan sabun cair dengan bahan aktif ekstra etanol daun karamunting $\left(\mathrm{F}_{2}\right)$ terhadap bakteri uji Escherichia coli dan Staphylococcus aureus menunjukkan bahwa $\mathrm{F}_{2}$ memiliki respon yang lebih besar dalam menghambat pertumbuhan bakteri uji dibanding $\mathrm{F}_{1}$ (Gambar 2).

Aktivitas antibakteri pada sediaan sabun cair dengan bahan aktif ekstrak etanol daun karamunting $\left(\mathrm{F}_{2}\right)$ bukan murni aktivitas antibakteri dari ekstrak karena pada sediaan sabun cair tanpa bahan aktif ekstra etanol daun karamunting $\left(\mathrm{F}_{1}\right)$ menunjukkan adanya zona hambat disekitar paper disc, yang menandakan bahwa $\mathrm{F}_{1}$ juga memiliki aktivitas antibakteri. Hal ini disebabkan karena gugus non polar dari sabun akan berikatan dengan dinding sel bakteri yang tersusun dari lipid sehingga dinding sel bakteri menjadi rusak dan menimbulkan lisis yang berakhir dengan kematian sel.

Untuk mengetahui aktivitas ekstrak dalam sediaan sabun cair maka aktivitas antibakteri dari $F_{2}$ dikurangi dengan aktivitas antibakteri dari $F_{1}$. Kemudian aktivitas ekstrak dalam sediaan yang didapat kemudian dibandingkan dengan aktivitas ekstrak yang telah diuji sebelumnya. Aktivitas antibakteri ekstrak etanol daun karamunting dengan konsentrasi $2 \%$ dalam sediaan sabun cair terhadap bakteri Escherichia coli dan Staphylococcus aureus adalah 5,908 $\mathrm{mm}$ dan 4,443 $\mathrm{mm}$, sedangan aktivitas antibakteri ekstrak etanol daun karamunting dengan konsentrasi $2 \%$ terhadap bakteri Escherichia coli dan Staphylococcus aureus adalah 6,481 $\mathrm{mm}$ dan 6,041 $\mathrm{mm}$. Sehingga terlihat bahwa adanya penurunan aktivitas antibakteri ekstrak.

Untuk mengetahui apakah terdapat perbedaan aktivitas antibakteri ekstrak etanol daun karamunting konsentrasi $2 \%$ dengan ekstrak etanol daun karamunting yang terdapat dalam sediaan sabun cair $\left(\mathrm{F}_{2}\right)$ maka data dianalisis menggunakan menggunakan program SPSS (Statistical Product of Service Solution). Dari data diameter zona hambat yang didapat dilakukan test homogeneity of variance dan didapatkan significant levelnya $>0,05$ yaitu sebesar 0,648 sehingga dapat dilakukan analisis varian (Anova) satu arah. Dari hasil analisis varian (Anova) didapatkan $\mathrm{F}$ hitung sebesar 0,527. $\mathrm{F}$ tabel dengan df untuk pembilang 1 dan df untuk penyebut 4 adalah 7,71 sehingga $F$ hitung lebih kecil dari $F$ tabel, maka tidak ada perbedaan nyata aktivitas antibakteri antara ekstrak etanol daun karamunting konsentrasi $2 \%$ dengan dengan ekstrak etanol daun karamunting yang terdapat dalam sediaan sabun cair dengan $\left(\mathrm{F}_{2}\right)$.

Tabel 5. Rangkuman hasil test homogeneity of variance dan analisis varian (Anova) aktivitas antibakteri ekstrak etanol daun karamunting konsentrasi 2\% dengan ekstrak etanol daun karamunting yang terdapat dalam sediaan sabun cair $\left(\mathrm{F}_{2}\right)$.

Test of Homogeneity of Variances

\begin{tabular}{|c|c|c|c|}
\hline $\begin{array}{l}\text { Levene } \\
\text { Statistic }\end{array}$ & $\mathrm{df} 1$ & df2 & Sig. \\
\hline .243 & 1 & 4 & .648 \\
\hline
\end{tabular}

ANOVA

\begin{tabular}{|c|c|c|c|c|c|}
\hline & $\begin{array}{l}\text { Sum of } \\
\text { Squares }\end{array}$ & $\mathrm{df}$ & Mean Square & $\mathrm{F}$ & Sig. \\
\hline Between Groups & .492 & 1 & .492 & \multirow[t]{3}{*}{.527} & \multirow{3}{*}{.508} \\
\hline Within Groups & 3.734 & 4 & .934 & & \\
\hline Total & 4.226 & 5 & & & \\
\hline
\end{tabular}




\section{KESIMPULAN}

Ekstrak etanol daun karamunting (Melastoma malabathricum) memiliki aktivitas antibakteri terhadap bakteri Escherichia coli dan Staphylococcus aureus. Konsentrasi terbaik ekstrak terbaik ekstrak etanol karamunting untuk kedua bakteri uji adalah 5\%. Sedangkan aktivitas antibakteri sediaan sabun cair dengan bahan aktif ekstrak etanol daun karamunting memiliki respon hambat yang lebih besar dibandingkan sediaan sabun cair tanpa bahan aktif ekstrak etanol daun karamunting.

\section{DAFTAR PUSTAKA}

[1] Joffry, S. Mohd, N. J. Yob, M. S. Rofiee, M. M. R. Moer Mohd. Afandi, Z. Suhaili, F. Othman, A.Md. Akim, M. N. M. Desa, dan Z. A. Zakaria. 2012. Melastoma malabathricum (L.) Smith Ethnomedicinal Uses, Chemical Constituents, and Pharmacological Properties: A Review. Artikel. Hindawi Publishing Corporation. Malaysia.

[2] Febriyanti, Rizky. 2014. Pengaruh Konsentrasi Asam Stearat sebagai Basis Terhadap Sifat Fisik Sabun Transparan Minyak Jeruk Purut (Oleum Citrus hystrix D. C.) dengan Metode Destilasi. Jurnal Politeknik Tegal. Vol. 3. No. 1.

[3] Rita, Wiwik Susanah. 2010. Isolasi, Identifikasi, dan Uji Aktivitas Antibakteri Senyawa Golongan Triterpenoid pada Rimpang Temu Putih (Curcuma zedoria (Berg.) Roscoe). Jurnal Kimia. Vol. 4. No. 1.

[4] Silalahi, Jansen dan Siti Nurbaya. 2011. Komposisi, Distribusi dan Sifat Aterogenik Asam Lemak dalam Minyak Kelapa dan Kelapa Sawit. Journal of the Indonesian Medical Association. Vol. 61. No. 11.

[5] Wijaya, Johan Iswara. 2013. Formulasi Sediaan Gel Hand Sanitizerdengan Bahan Aktif Triklosan 1,5\% dan 2\%. Jurnal IlmiahMahasiswa Universitas Surabaya. Vol. 2. No. 1. 